
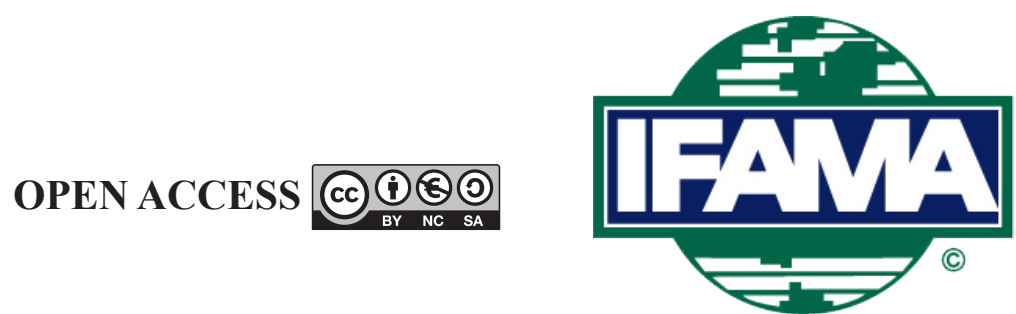

International Food and Agribusiness Management Review

Volume 24, Issue 4, 2021; DOI: 10.22434/IFAMR2020.0197

Received: 1 December 2020 / Accepted: 29 March 2021

Special Issue: Growth of agroholdings and mega-farms in transition and emerging market economies: institutional and organizational aspects

\title{
Determinants of corporate social responsibility among farms in Russia and Kazakhstan: a multilevel approach using survey data RESEARCH ARTICLE
}

\author{
Anna Hajdu ${ }^{(1)}$, Taras Gagalyuk ${ }^{\mathrm{b}}$, Eduard Bukin ${ }^{\mathrm{c}}$ and Martin Petrick ${ }^{\mathrm{d}, \mathrm{e}}$ \\ ${ }^{a}$ PhD Candidate, ${ }^{b}$ Research Associate, ${ }^{e}$ Visiting Research Fellow, Leibniz Institute of Agricultural \\ Development in Transition Economies (IAMO), Theodor-Lieser-Str. 2, 06120, Halle (Saale), Germany \\ ${ }^{c}$ PhD Candidate, Institute of Agricultural Policy and Market Research, Justus Liebig \\ University Giessen, Senckenbergstrasse 3, 35390, Giessen, Germany \\ ${ }^{d}$ Professor, Center for International Development and Environmental Research (ZEU), \\ Justus Liebig University Giessen, Senckenbergstrasse 3, 35390, Giessen, Germany
}

\begin{abstract}
Building on the institutional theory of corporate social responsibility (CSR) and research on CSR in the agriculture of post-Soviet transition economies, the present paper investigates the institutional, organizational and individual factors of farm engagement in CSR activities. Based on a survey of 800 farms in Russia and Kazakhstan, the interaction between the farms' social role and multilevel institutional characteristics is addressed. We observe notable positive effects of local labor sourcing, insecure land use conditions and farm size (in terms of land area) on farms' CSR engagement. Individually owned farms, as opposed to corporate farms, tend to be more CSR affine. In addition, we find weak statistical evidence of CSR engagement among the farms affiliated with agroholdings. We discuss the results in the context of different levels of CSR analysis.
\end{abstract}

Keywords: corporate social responsibility, primary agriculture, organizational-level factors, institutionallevel factors, transition economies

JEL code: Q15, O130, Q130, M140, Q170, R110

${ }^{\circledR}$ Corresponding author: hajdu@iamo.de 


\section{Introduction}

Corporate social responsibility (CSR) is generally considered an action that appears to further some social good, beyond the interests of the firm and that which is required by law (McWilliams and Siegel, 2000: 117). According to institutional scholars, pressures arising at the institutional, organizational and individual (personal) levels motivate CSR activities (Aguinis and Glavas, 2012; Campbell, 2007; Lin et al., 2017). Scholars have increasingly recognized the interplay between institutional and organizational levels that determines CSR engagement (Aguilera et al., 2007; Vaz et al., 2016; Wood, 1991). Little focus has been directed so far on empirically analyzing all three levels. However, it is important to do so to fully understand the underlying motivations for CSR (Aguinis and Glavas, 2012). In addition, focusing on all three levels helps to recognize existing and potential frictions between the levels that may hamper organizations' CSR commitment and implementation (McWilliams and Siegel, 2000).

The present paper aims to fill the above gap by studying CSR at the institutional, organizational and individual levels. We apply a multilevel framework of CSR to quantitatively analyze the drivers of CSR engagement in the agricultural sector of newly emerging global breadbaskets - Russia and Kazakhstan. While the agricultural sector has increasingly become a focus of societal scrutiny (Balmann et al., 2016; Heyder and Theuvsen, 2012), the concept of CSR has still scarcely been researched in the context of both primary agriculture and transition countries. We adopt institutional theory and its offspring, such as stakeholder theory and the resource-based view of the firm, which outline a number of factors that impact CSR engagement. Drawing upon a survey of 800 farms in six provinces of Russia and Kazakhstan, we analyze the determinants of CSR activity at the farm level using logistic regression analysis. In doing so, we extend the existing CSR literature in several ways.

First, we contribute to the generally limited knowledge about CSR in primary agriculture. Related studies focus mainly on consumer-proximate industries and deal with the institutional- and organizational-level factors of CSR in the agri-food business (Hartmann, 2011; Heyder and Theuvsen, 2012). However, it is also important to address CSR in primary agriculture since policymakers and development specialists have recognized it as a feasible driver for rural development (Arato et al., 2016). Hajdu et al. (in press) have developed such a qualitative study focusing on primary agriculture in Argentina and show the institutional and individual-level motivations for CSR in the large farms and agroholdings studied.

Second, in contrast to developed countries where CSR analyses are widespread (Li and Zhang, 2010), research on CSR in post-Soviet transition economies is particularly scarce. Notable exceptions in agribusiness research have appeared only recently and include studies by Gagalyuk et al. (2018) and Gagalyuk and Valentinov (2019) for Ukraine and Grouiez (2014), Visser et al. (2019) and Bavorová et al. (2021) for Russia. At the same time, research on CSR in Kazakhstan, an important player in global agricultural markets, is missing. By focusing on the CSR engagement of farmers in Russia and Kazakhstan, our study is the first of its kind to fill this gap.

Third, the mentioned studies on CSR in post-Soviet agriculture focus predominantly on the institutional-level drivers of CSR. Based on qualitative case studies and in-depth interviews, they find that post-Soviet path dependencies, inconsistent land and rural development policies, imperfections of agricultural factor markets and regional power configurations influence farmers' CSR engagement (Gagalyuk et al., 2018; Grouiez, 2014; Visser et al., 2019). The study by Bavorová et al. (2021) quantitatively assesses the effects of farmlevel indicators and individual farm managers' characteristics on the farms' support of rural infrastructure. However, altogether, these studies fail (or do not aim) to address all three levels of CSR analysis simultaneously. Our multilevel approach extends these research efforts and verifies their results. In addition, our framework includes several important factors, such as production specialization and farm managers' gender and education, which were outside of the focus of the mentioned studies. 
Fourth, except for the research by Bavorová et al. (2021), the studies on farms' CSR in transition economies focus exclusively on the CSR of large-scale agroholdings (Gagalyuk et al., 2018; Grouiez, 2014; Visser et al., 2019). Structurally, these large farming entities represent horizontally and vertically integrated enterprises consisting of a mother company that controls and manages numerous corporate farms and operates dozens or even hundreds of thousands of hectares (Hermans et al., 2017; Visser et al., 2012). Previous studies show that agroholdings engage in CSR to resolve their problems of legitimacy, access to farmland and labor, while some moral considerations of agroholding managers also play a role (Gagalyuk et al., 2018). At the same time, socially responsible activities of farm types other than agroholdings remain scarcely researched. By differentiating between corporate and individual (family) farms in our framework, we extend previous research on CSR in the agricultural sector of transition economies. We also assess whether agroholding affiliation affects farms' CSR.

Our findings indicate notable positive effects of local labor sourcing, insecure land use conditions and farm size (in terms of land area) on farms' CSR engagement. Individually owned farms, as opposed to corporate farms, tend to be more CSR affine. In addition, we find weak statistical evidence of CSR engagement among the farms affiliated with agroholdings.

The remainder of the article is structured as follows. First, we outline the empirical context of our study - the agricultural sectors of Russia and Kazakhstan and their evolution during the past three decades. Second, we elaborate theoretically and review up-to-date empirical evidence to develop hypotheses on the effects of the institutional environment and organizational-level and individual-level characteristics on farmers' engagement in CSR. Third, we describe the survey design and data. Fourth, we present and discuss the results of the regression analysis. Finally, we conclude and make propositions for future research on CSR in agribusiness.

\section{Institutional forces, farm structures and corporate social responsibility in Russia and Kazakhstan}

Historically, a dichotomy of large-scale collective (kolkhoz) and state (sovkhoz) farms versus small-scale subsistence farming dominated all Soviet Republics. In addition to being a major source of food and agricultural products for the urban population, the Soviet Republic's large-scale farms were nearly exclusive employers for the rural population (Pallot and Nefedova, 2007). The Soviet Union's decay left all other former republics with a similar legacy. Different approaches to the institutionalization of private property rights, land reform, farm decollectivization and restructuring led to three dominant forms of agricultural producers in Russia and Kazakhstan: (1) agricultural enterprises; (2) individual farms; and (3) subsistence rural household farms.

Agricultural enterprises represent corporate farms of various legal forms that include limited liability companies, joint stock companies, partnerships and agricultural cooperatives. An individual farm refers to a legal entity created by an individual, a family or a group of individuals on the basis of jointly owned land and assets. Individual farms rely mainly on family labor and family-owned resources, although they may employ hired labor and leased resources. The main objectives of agricultural enterprises and individual farms are commercial. The third type of farm, rural households, produces to primarily satisfy the consumption needs of the family members. Surplus products may be sold outside of the household, and the income from sales of farm products from the household farm is exempt from taxes. Similar to individual farms, rural household farms operate as individuals and rely on family labor. However, in contrast to individual farms, rural household farms operate without formal registration. Individual farms, such as agricultural enterprises, are subject to taxes, but the legislation that applies to them differs substantially from corporate legislation and typically comes along with some tax simplifications or exemptions. In contrast to corporate and individual farms, rural household farms have very limited access to commercial credit and rarely receive any financial support from the state (Lerman et al., 2004; Petrick and Oshakbaev, 2015).

While being a cornerstone of the Soviet rural economy, collective farms were also central to the life of rural communities during the Soviet period. They maintained a tight 'informal contract' between large- 
scale producers and the rural population. Economically, such symbiosis implied (and often forced) a flow of labor from rural households to large-scale farms. However, in exchange, workers gained wage top-ups and subsistence farming support that was informally encouraged by the collectives (Visser et al., 2019; Wädekin, 1973). Due to this symbiosis, the rural population received secure employment and gained access to production inputs such as seeds, fertilizers, machinery, etc. In the long term, such symbiosis provided rural communities with secure employment, social services (education, medicine, legal services, cultural life, etc.) and infrastructure (roads, post, electricity, water, sanitation, energy resources, etc.).

The end of the Soviet era and ensuing farm restructuring dismantled this social contract. No central planning office forced the agricultural enterprises to continue their social obligations anymore. Legislation entrusted local authorities with the task of providing social, cultural, entertaining and servicing facilities, formerly residing with collective and state farms, while some facilities were privatized. However, central governments did not provide sufficient financial resources to allow local authorities to meet their new responsibilities (Wegren, 2009). As a result, many social facilities were closed, whereas privately owned facilities adopted a commercial orientation with higher service charges that took them out of reach for average rural people. With decollectivization and privatization, a substantial share of the rural population became unemployed. An increasing migration of the economically active population to urban regions and an increasing mortality rate among elderly individuals within the rural population have emerged as a consequence (Pallot and Nefedova, 2007; Wegren, 2009).

Along with the recovering productivity and profitability of agribusinesses in Russia and Kazakhstan, farming enterprises in transition economies face a substantial moral burden due to high societal expectations. Grouiez (2014), Gagalyuk et al. (2018), and Visser et al. (2019) have shown that local rural communities, farm employees and local authorities are primary claimants for various sorts of social support from agroholdings in Russia and Ukraine. In part, the reminiscences of the abovementioned symbiosis between agricultural enterprises and rural households that existed during Soviet times (Gagalyuk and Schaft, 2016) drive these expectations. However, new expectations of the farming sector arose in the transition period as a result of worsening living conditions in rural areas (Gagalyuk et al., 2018; Grouiez, 2014; Visser et al., 2019).

To meet these expectations, farming enterprises may conduct various CSR activities. For instance, agroholdings in Russia sponsor social infrastructure and services, such as clearing roads from snow and supporting schools and culture clubs (Visser et al., 2019). Furthermore, in Ukraine, agroholdings support individual rural inhabitants and invest in improvements of rural technical infrastructure: roads, electricity lines, and water and gas pipelines, as found by Gagalyuk et al. (2018). Based on these findings, we adopt the definition used by Visser et al. (2019) and Bavorová et al. (2021) of CSR as the social and technical infrastructure provided by farms in rural areas. This is in line with CSR scholars who have increasingly pointed to the relevance of contextual factors in defining corporate social responsibility activities (Amaeshi et al., 2006; Fifka and Pobizhan, 2014; Matten and Moon, 2008; Pisani et al., 2017; Tilt, 2016) and in considering how CSR is locally embedded (Amaeshi et al., 2006). Existing theories and scarce empirical evidence suggest that factors shaping the types of CSR activities undertaken by farming enterprises in transition economies pertain to different levels.

\section{Theoretical background: levels of corporate social responsibility analysis}

The corporate social responsibility activities of organizations are influenced and implemented by actors at different levels. Institutional theory widely recognizes three levels of analysis of antecedents and outcomes of CSR activities, namely, the institutional, organizational, and individual levels (Aguilera et al., 2007; Aguinis and Glavas, 2012; Wood, 1991). Wood (1991) showed that the CSR activities of businesses are reflective of the pressures arising at these levels. Defined at the institutional level, CSR is a way to respond to the pressures of legitimacy and power that society grants to businesses. At the organizational level, it represents public responsibility for problems and social issues that derive from business operations and interests. At the individual level, it is characterized by managerial discretion or the morality of managers. In their extensive 
review of the CSR literature, Aguinis and Glavas (2012) found a dearth of individual-level focus of CSR analysis and called for the advancement of CSR research through the integration of a multilevel analysis. We respond to this call by simultaneously analyzing the drivers of CSR at three different levels. The present section builds upon up-to-date theoretical and empirical research to develop hypotheses on the drivers of farmers' CSR engagement in transition economies of Russia and Kazakhstan. Our study does not inquire directly about the motivations for CSR implementation. Instead, it focuses on a broader set of internal and external contextual factors that shape the motivations of farmers to engage in CSR activities.

\subsection{Institutional level factors of corporate social responsibility engagement}

Imperfections of the legal system in conjunction with incomplete land reforms are among the major pressures on the agribusiness sector of transition economies (Kvartiuk and Petrick, 2021; Wegren, 2009). Farmers may be compelled to provide social services to their rural communities (e.g. construction of roads, gas and water supply pipelines, electricity lines and so on) to secure land leases in the long term (Gagalyuk and Valentinov, 2019).

In the case of Krasnodar Krai in Russia, Visser et al. (2019) found that lease agreements were established for 10 years. Even in such cases, the best way to ensure farming enterprises against the insecurity of losing land is to provide social support, as the authors further argue. For Altai Krai of Russia, Bavorová et al. (2021) reported that maintaining good relations with local authorities ensures access to land. Therefore, investing in developing communities is a way for farmers to ensure long-term land use in an uncertain environment. Additionally, unlike Ukraine, where a moratorium on farmland sales seems to drive farmers' CSR engagement, Russia has a full-fledged land market whereby both lease- and ownership-based land uses are in place. We thus hypothesize the following:

H1a: With increasing land use insecurity, the engagement of farmers in corporate social responsibility activities increases.

H1b: With an increasing share of leased land in a farm's land use, the engagement of farmers in corporate social responsibility activities increases.

The dynamics of the agricultural labor market are also subject to institutional turbulence in transition economies. Unsuccessful rural development policies, which tended to prioritize the development of commercial agriculture over the maintenance of social infrastructure, resulted in poor publicly provided safety nets and substantial outmigration of rural citizens to urbanized areas (Bednaříková et al., 2016; Wegren and Elvestad, 2018; White, 2007) and to other countries (Kvartiuk et al., 2020). Several studies point to the high need for skilled workers in rural Russia (Unay-Gailhard et al., 2019; Visser et al., 2019), especially in large-scale agriculture (Kvartiuk et al., 2020). This problem compels farmers, especially large agroholdings, who are often a single employer in a village, to develop rural social infrastructure (schools, kindergartens and hospitals) and design qualification improvement programs for their own and for potentially recruited employees (Gagalyuk et al., 2018; Visser et al., 2019). In addition, some agroholdings have been found to design above-average compensation packages for workers to attract talented employees (Gagalyuk et al., 2018). Farmers attempt to reduce the outflow of labor from their rural communities.

Attracting seasonal employees from outside the region of farm operations can be one of the solutions of the labor deficit problem. In addition, it can provide an opportunity for a farm manager to engage in off-farm activities, including CSR. However, the study by Visser et al. (2019) also shows that such labor market dynamics should be treated as context-specific. In labor-abundant Krasnodar Krai of Russia, characterized by proximity to the heavily populated north Caucasus republics and high in-migration rates from these republics, pressures of worker deficits on agroholdings are much lower. Therefore, agroholdings have less interest in supporting local rural communities. Thus, farmers in labor-abundant regions and regions with 
the opportunity to hire migrant and seasonal workers may be less prone to engage in CSR. Accordingly, we hypothesize the following:

H2a: With increasing reliance on local labor, the engagement of farmers in corporate social responsibility activities increases.

H2b: With an increasing share of seasonal labor in a farm's employment structure, the engagement of farmers in corporate social responsibility activities decreases.

Another feature of the institutional environment in transition countries is the underdeveloped financial markets. Stock markets are either volatile or poorly functioning, while commercial banks provide loans under very restrictive refinance rates (Gagalyuk and Valentinov, 2019). Large-scale agroholdings are generally able to overcome these difficulties by attracting outside investors, listings on international stock exchanges and lending from international financial institutions (IFIs), such as the International Finance Corporation (IFC) and European Bank for Reconstruction and Development (EBRD) (Gagalyuk, 2017; Petrick et al., 2013). Moreover, to receive loans from renowned lenders such as IFC and EBRD, agroholdings have to comply with the IFIs' extensive requirements for corporate conduct, which have been shown to stimulate agroholdings' commitment to CSR (Gagalyuk and Valentinov, 2019).

However, a poor financial condition of firms is generally associated with less CSR (Campbell, 2007), while the majority of commercial farms in countries such as Russia and Kazakhstan are small individuals as well as corporate non-agroholding farms. Unlike agroholdings, they have generally less favorable conditions to access capital. For instance, small farms in northern Kazakhstan encounter more difficulties related to access to finance, inputs and marketing channels than larger vertically integrated farms (Dudwick et al., 2007; Petrick et al., 2017). To this end, access to credit is still limited in the Russian agricultural sector (Lioubimtseva and Henebry, 2012; Nizalov et al., 2015). We therefore hypothesize the following:

H3: With increasing credit constraints, the engagement of farmers in corporate social responsibility activities decreases.

Problems of illegal business takeovers, corporate raiding and land grabbing have been shown to frequently threaten the agricultural business environment in countries such as Russia, Ukraine, and Kazakhstan (Gagalyuk and Valentinov, 2019; Oshakbayev et al., 2018; Visser et al., 2012). Non-agroholding farms are particularly exposed to these negative developments (Gagalyuk and Valentinov, 2019). This evidence points to the inability (or unwillingness) of the existing legal system to prevent such illegal behavior. If farms recognize this inability and find themselves unable to change the status quo by appealing to the legal system, they may attempt to establish productive exchange with their stakeholders through credible commitments or 'hostages' (Jauernig and Valentinov, 2019; Williamson, 1983) in the form of CSR. In Williamson's (1996: 56) interpretation, the tendency of opportunistic behavior leads to social dilemmas between exchange parties, while the adoption of CSR that fulfills the function of credible commitments can forestall such opportunism. The motivation for such CSR can be simultaneously moral and instrumental (Jauernig and Valentinov, 2019; Visser et al., 2019). We thus hypothesize the following:

H4: With increasing farmers' distrust in the country's legal system, their engagement in corporate social responsibility activities increases.

\subsection{Organizational level factors of corporate social responsibility engagement}

Earlier research on corporate social performance and social change in organizations has shown that it is important to consider the complementarities and conflicts between external institutional factors and internal organizational drivers of CSR (Aguilera et al., 2007; Wood, 1991). One of the most notable interlevel frictions that may arise in this regard is associated with the necessity to devote organizational resources to deal with 
external pressures for CSR (McWilliams and Siegel, 2000). Accordingly, the resource-based view of the firm (RBV) presents a useful framework to study factors of CSR engagement at the organizational level (i.e. farm level in the context of this article). The core idea of RBV is that the firms' idiosyncratic attributes, such as assets and competences, represent valuable, rare, inimitable and nonsubstitutable resources that generate sustained competitive advantage (Barney, 1991; Wernerfelt, 1984).

In particular, the RBV highlights the importance of organizational size as a factor for CSR engagement. Many studies have focused on identifying the relationship between organizational size in terms of the number of employees and CSR activities (Arato et al., 2016; Orlitzky, 2001; Stanwick and Stanwick, 1998). Organizational size has been found to be positively associated with philanthropic expenditure (Adams and Hardwick, 2002; Brammer and Millington, 2006; McElroy and Siegfried, 1985). Economies of size likely decrease the cost of CSR activities for larger farms (Ho and Taylor, 2007). Larger companies are also more visible and are subject to greater pressures from the general public to improve their societal and environmental impacts (Bavorová et al., 2021; Gagalyuk, 2017).

For the agribusiness and food sectors, studies by Hartmann (2011), Heyder and Theuvsen (2012) and Bourlakis et al. (2014) confirmed that size is an important determinant of CSR engagement. Bavorová et al. (2021) found a positive relationship between farm size and the support of social and technical rural infrastructure in Russia. For Ukraine, Gagalyuk (2017) and Graubner et al. (2021) revealed that primarily large and resourceful agroholding-affiliated farms, driven by considerations of positive image in local communities and of securing farmland from competitors, engage in various CSR initiatives. Thus, empirical research produces mixed results with regard to the effects of farm agroholding affiliation on CSR engagement. We therefore predict a positive relationship between farm size and farmers' CSR engagement as well as between farm affiliation with agroholding and CSR engagement:

H5: With increasing farm size, the engagement of farmers in corporate social responsibility activities increases.

H6: With a farm's agroholding affiliation, the engagement of farmers in corporate social responsibility activities increases.

The abovementioned agroholdings predominantly consist of corporate farms (Hermans et al., 2017). At the same time, commercial farming in Russia and Kazakhstan is, for the most part, conducted by farms of other legal forms and ownership types, such as individual and non-agroholding corporate farms (cooperatives, joint stock companies, limited liability companies, etc.). Enterprise ownership/legal forms are considered to play a role in CSR (Li and Zhang, 2010), but research on the effect of legal forms on CSR is scarce, especially in transition economies (Bavorová et al., 2021; Fifka and Pobizhan, 2014). The present study distinguishes between the CSR engagement of individual (family) farms and corporate farms (including both affiliated and non-affiliated with an agroholding), as these types of ownership are typical of commercial farms in Russia and Kazakhstan (Kvartiuk and Petrick, 2021; Wegren, 2018). With this differentiation, we extend previous research on CSR in post-Soviet agriculture that focused mainly on the CSR of corporate agroholdings.

In their social responsibility activity, individual and corporate enterprises may differ due to the effects of diverse stakeholders and regulatory environments that shape the adoption of CSR practices. In particular, corporate enterprises may face greater challenges than individual enterprises due to a broader set of pressures pertaining to both general public and private investor interests (Gagalyuk, 2017; Panwar et al., 2014). However, the CSR of individual enterprises in the primary agriculture sector has been considerably understudied compared to the widely reported CSR of agroholdings. We therefore assume that they may be involved in a range of implicit CSR activities (Visser et al., 2019), i.e. non-reported CSR. To this end, interactions and cooperation among farmers themselves are conducive to the farms' performance in terms of the social support provided to employees and to communities (Bavorová et al., 2021; Smedley, 2012). The reasons for this involvement may vary from instrumental motives, such as additional protection of farm assets under the full liability 
condition, to moral considerations such as self-identification with a village. We therefore expect the CSR of individual and corporate farms in our Russian and Kazakh cases to differ, with individual farmers being more prone to engage in CSR:

H7: With individual farm ownership, the engagement of farmers in corporate social responsibility activities increases.

H8: With farmers cooperating with each other, the engagement of farmers in corporate social responsibility activities increases.

We expect that another farm-level factor significantly affects farmers' engagement in CSR, namely, production specialization. During the transition, livestock production has considerably declined in Russia, Ukraine and other post-Soviet countries. Former kolkhozes have transformed from diversified farm entities into mostly crop-producing farms (Visser et al., 2019), while the new production form, agroholdings, has specialized in crop production almost by default (Graubner et al., 2021). However, livestock production in Russia is gradually recovering. Since livestock producers are largely associated with negative environmental impacts by the general public and are more labor intensive and consumer proximate than crop producers, they face higher pressures for CSR activities (Heyder and Theuvsen, 2008). We thus hypothesize the following:

H9: With increasing farm specialization in livestock production, the engagement of farmers in corporate social responsibility activities increases.

\subsection{Individual level factors of corporate social responsibility engagement}

The microlevel of CSR analysis reflects the individual motivations, traits and attitudes as well as psychological processes for CSR engagement (Aguinis and Glavas, 2012). This level emphasizes questions of behavioral conduct, moral values of individuals or their characteristics (leadership profiles, age, education, gender, etc.). Our empirical analysis focuses on farm managers' sociodemographic characteristics, such as age, gender and education, as individual factors influencing CSR engagement.

Bavorová et al. (2021) propose that farmers' age can play a positive role in CSR engagement. They assume that older farm managers would be more CSR-affine because they may remember Soviet times when collective farms were responsible for the delivery of social services in rural areas. We therefore hypothesize the following:

H10: With an increase in farm managers' age, the engagement of farmers in corporate social responsibility activities increases.

Interest in studying the impact of women in management positions on CSR practices and CSR performance has increased in recent years (Adams and Ferreira, 2009; Bear et al., 2010; Boulouta, 2013; Larrieta-Rubín de Celis et al., 2015; Setó-Pamies, 2015; Soares et al., 2011; Zhang et al., 2013). However, studies on the effects of gender on CSR in transition economies are very scarce. Tleubayev et al. (2020) found a strong positive relationship between female representation on corporate boards and firm performance in the Russian agri-food business. In line with this finding, we hypothesize the following:

H11: With a female farm manager, the engagement of farmers in corporate social responsibility activities increases. 
A higher level of formal education and training has shown a positive effect on the implementation of social welfare policies in companies (Quazi, 2003). Thus, we hypothesize the following:

H12: With higher education, college education and agricultural education of a farm manager, the engagement of farmers in corporate social responsibility activities increases.

\section{Methods}

\subsection{Data description}

The subsequent analysis draws on survey data collected from a sample of 800 agricultural producers in 2019: 600 farms in Russia and 200 in Kazakhstan. In Russia, questionnaires were administered among 120 randomly selected farms in five provinces (Belgorod, Ryazan, Stavropol, Altai Krai and Novosibirsk). In Kazakhstan, 200 farms were sampled randomly in Akmola Province. These regions were purposively selected for data collection to capture the diversity of the main agricultural regions in Russia, inside and outside of the black earth region, European and Siberian regions and the major grain-producing region of Kazakhstan (Petrick and Götz, 2019).

Between March and June 2019, professional enumerators collected the data in a series of face-to-face interviews with farm managers, owners or persons who participate in the decision-making process of the farm. The data capture inputs and outputs of crop and livestock production in the one-year period preceding the data collection. In each of the six provinces, up to six districts were purposefully selected. Then, in each district, 30 to 50 farms (for Russia or Kazakhstan) were randomly selected from the total population of actively operating farms. Local governments provided the population lists of farms in 2015 for a previous wave of the farm survey, which did not focus on CSR (Petrick and Götz, 2019). To compensate for attrition, additional districts were added in 2019. See Supplementary Table S1 for details on the attrition.

To determine whether a farm participates in CSR activities, we asked interviewees four questions on whether their farm conducts CSR activities targeting the development of: (1) the local community; (2) rural inhabitants; (3) physical infrastructure; or (4) social infrastructure. Each question allowed for Yes/No/Don't know answers. ${ }^{1}$ Finally, based on the four questions, we constructed a dependent variable 'conducts any CSR activity', which takes the value of 'Yes' if any of the four CSR variables states 'Yes', 'No' if all non-missing CSR variables are 'No', and 'Do not know' if all CSR variables have a missing answer.

Figure 1 summarizes the frequencies of answers to the CSR questions by province, suggesting substantial differences between the provinces. In Russia, in Ryazan, approximately 39\% of farmers conduct some CSR, showing no distinct preference for any specific type. In Belgorod, farmers tend to focus on physical infrastructure development approximately three times more frequently than on other CSRs. Other provinces of Russia demonstrate low rates of CSR activities. In Akmola in Kazakhstan, approximately $73 \%$ of farms perform some type of CSR activities, favoring local community development in $63 \%$ of cases.

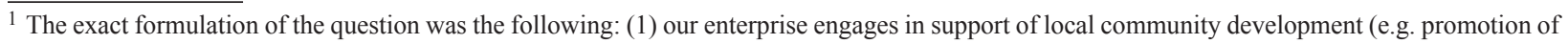
entrepreneurship or cooperation among rural inhabitants, provision of legal or economic advice to rural inhabitants, etc.); (2) our enterprise engages in individual support of rural inhabitants (e.g. help with education of young people, medical treatment of elderly people, provision of machinery to inhabitants to farm their individual land plots, etc.); (3) our enterprise engages in support of development of physical infrastructure (e.g. repair and construction of roads, cleaning of roads/drains, installation of electricity lines/water pipes, landscaping, etc.); (4) our enterprise engages in support of development of social infrastructure (e.g. construction/equipment of schools/kindergartens/hospitals, charitable giving, etc.).
} 


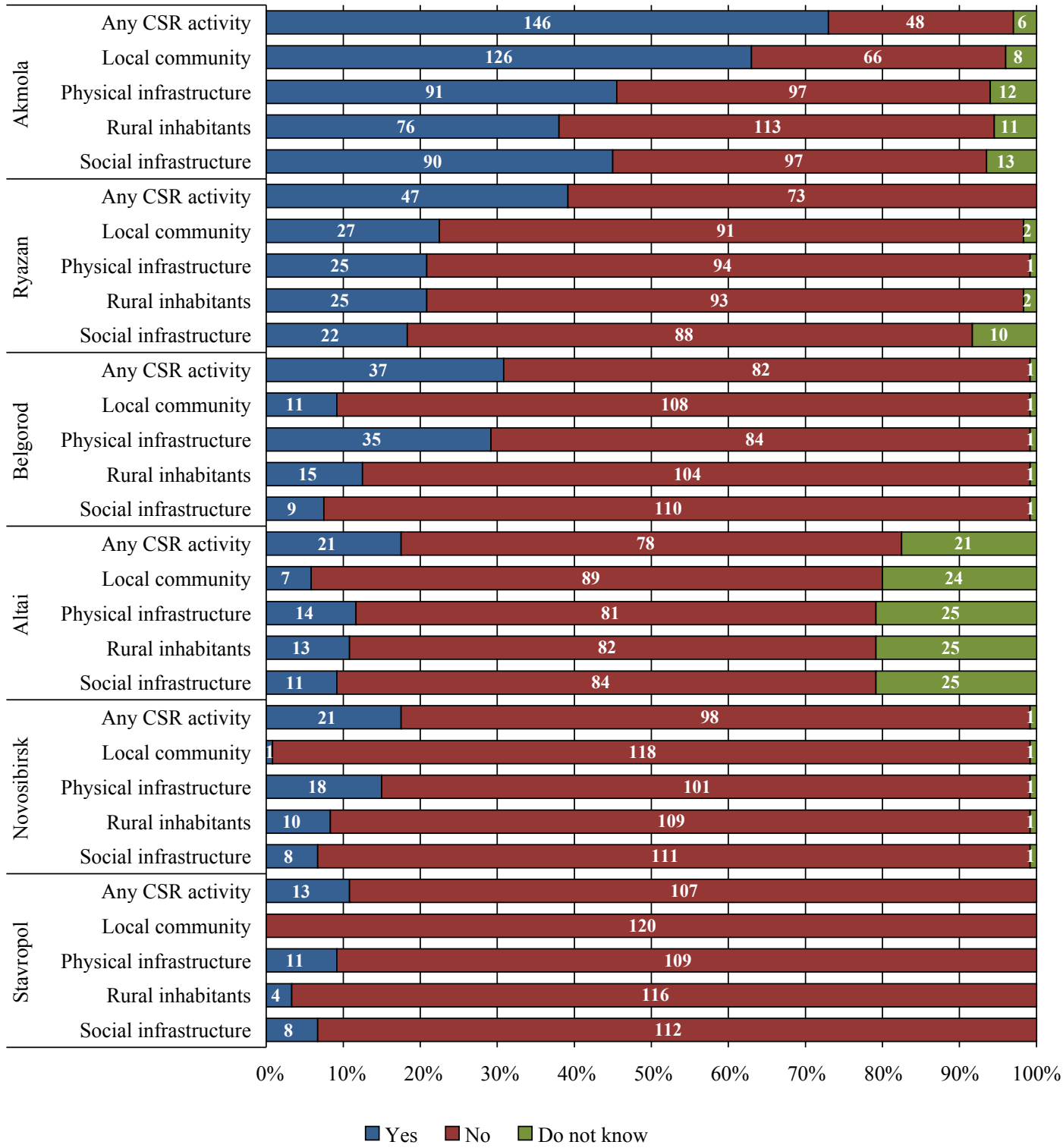

Figure 1. Corporate social responsibility (CSR) activity by province. Provinces are ordered by descending frequency of 'Yes' in the dependent variable of conducting any CSR activities.

\subsection{Model specification and summary statistics}

To identify the determinants of CSR, we estimate a logistic regression model, assuming that the logit transformation is an appropriate approximation to the binary dependent variable CSR, which is ' $1=$ Yes' for farms conducting and ' $0=$ No' for farms not conducting any CSR activities. We dropped 29 observations that contained the 'Do not know' value and estimated the following model (Greene 2020: 776):

$$
\log (P / 1-P)=\beta X
$$

where $P$ is the probability of a farm engaging in CSR, so that $P / 1-P$ is the odds ratio. $X$ is a vector of determinants, and $\beta$ is a parameter vector to be estimated. An odds ratio equal to one means an equal chance of engaging or not engaging in CSR. Values higher than one increase the chance, and lower values decrease it. 
The vector of independent variables consists of continuous, categorical and indicator variables (Supplementary Table S2 and S3).

Among the institutional-level factors to test Hypotheses 1 to 4, we include the farmers' response to the question 'How likely is it that you may lose your ownership or land use right in the next 3 years?', measured on a Likert scale from 1 to 5, where $1=$ absolutely unlikely and 5=absolutely likely. Moreover, we include the share of rented-in land in total land use ( 0 to 1$)$ and the total, permanent and seasonal labor in full-time equivalent (FTE) computed as the total number of days that all types of labor (seasonal and permanent, hired and household-based) worked on the farm (in both livestock and crop production) divided by 242 (the typical number of working days in a year). In addition, there are indicator variables for local seasonal labor if seasonal workers are hired from the local community, if any land is rented out, and if the farm is classified as a credit constraint. The credit constraint indicator takes the value of one if a farm applied for credit in the previous twelve months and was refused (liquidity-constrained), or it was granted an amount that was less than requested (quantity constrained); see Petrick et al. (2017) for details on this methodology. We also incorporated the manager's trust in farmers, investors and the state, each measured on a Likert scale from $1=$ never trust to $5=$ always trust.

To test Hypotheses 5 to 9 at the organizational level, we include total land, rented-in and owned land areas in hectares (ha) and the monetary value of fixed capital and machinery in thousands 2019 USD. Based on self-reporting by the respondents, we indicate whether the farm belongs to an agroholding farm or is an individual farm. Corporate farms are the residual category of these two indicators. Farms that cooperate with others in production activities are indicated as well, and whether a farm produces any crops or any livestock.

At the individual level and referring to Hypotheses 10 to 12, we use indicator variables of the manager's gender, college education and any agricultural training along with the manager's age and an education index. The index ranges from 3 for incomplete secondary education to 8 for higher education.

To take into account provincial differences, indicator variables for provinces are included with Stavropol omitted to intercept (as the province with the lowest CSR rate). Finally, a set of reverse dummy variables is used to account for zero input use and not-reported observations following Battese (1997).

We specify three models: Model 1 is our reference, Model 2 employs an alternative specification of land and labor, and Model 3 excludes the monetary variables fixed capital and value of machinery. Model 2 is specified to check the robustness of the results with regard to alternative measurements of land and labor variables. Model 3 explores the robustness of the estimates when the monetary variables are left out, as these may suffer most from imprecise measurement and missing observations. In all three specifications, the selected variables did not exhibit any problematic collinearity. The estimation results reported as odds ratios are presented in Table 1.

Finally, for each model, we compute goodness of fit measures and tests to validate their qualities. Overall, all three models appear to be appropriate for the data (based on a highly significant likelihood ratio (LR) test). Moreover, all models show an excellent goodness of fit based on the pseudo R-square as well as the area under the receiver operating characteristic (AUC) curve (Hosmer et al., 2013: 173-182), which is above $85 \%$ for all models, or the coefficient of discrimination (Tjur, 2009), which suggests that approximately $40 \%$ of variance is explained.

\section{Results}

In support of Hypothesis 1a (H1a), we find that a farmer's subjective assessment of the likelihood of losing land has a positive and robust effect on the odds of CSR engagement. An increase in the perception that losing the land is likely by one point on the Likert scale increased the odds of engaging in CSR activities by a factor of 1.8 . 
Table 1. Logistic regressions of engagement in corporate social responsibility activities. ${ }^{1,2}$

\begin{tabular}{|c|c|c|c|c|c|c|}
\hline \multirow[b]{2}{*}{ Intercept } & \multicolumn{2}{|l|}{ Model 1} & \multicolumn{2}{|l|}{ Model 2} & \multicolumn{2}{|l|}{ Model 3} \\
\hline & $<0.1 * * *$ & $(<0.001)$ & $<0.1 * * *$ & $(<0.001)$ & $<0.1 * * *$ & $(<0.001)$ \\
\hline Individual farm $(0 \mid 1)$ & $2.5 * *$ & $(0.005)$ & $2.6 * *$ & $(0.004)$ & $2.6 * *$ & $(0.004)$ \\
\hline Agroholding $(0 \mid 1)$ & $13.4 *$ & $(0.031)$ & $12.0 *$ & $(0.031)$ & 7.0 & $(0.079)$ \\
\hline Crop $(0 \mid 1)$ & 0.4 & $(0.095)$ & 0.4 & $(0.110)$ & 0.5 & $(0.160)$ \\
\hline Livestock $(0 \mid 1)$ & $2.0 * *$ & $(0.005)$ & $1.8 *$ & $(0.018)$ & $2.0 * *$ & $(0.004)$ \\
\hline Farm cooperates with others $(0 \mid 1)$ & 2.3 & $(0.078)$ & 2.0 & $(0.143)$ & 1.9 & $(0.128)$ \\
\hline Total land use (log), ha & $1.5 * * *$ & $(<0.001)$ & & & $1.5 * * *$ & $(<0.001)$ \\
\hline Owned land area $(\log )$, ha & & & $1.4^{* * *}$ & $(<0.001)$ & & \\
\hline Rented land area $(\log )$, ha & & & $1.5 * * *$ & $(<0.001)$ & & \\
\hline Share of land rented in $(0 \ldots 1)$ & $2.0 *$ & $(0.045)$ & & & $2.1 *$ & $(0.020)$ \\
\hline Any land rented out $(0 \mid 1)$ & 5.9 & $(0.101)$ & 7.2 & $(0.070)$ & 4.3 & $(0.119)$ \\
\hline Labor $(\log )$, FTE & 0.9 & $(0.382)$ & & & 0.9 & $(0.241)$ \\
\hline Share of seasonal labor $(0 \ldots 1)$ & 0.7 & $(0.511)$ & & & 0.5 & $(0.317)$ \\
\hline Permanent labor (log), FTE & & & 1.0 & $(0.975)$ & & \\
\hline Seasonal labor (log), FTE & & & 1.0 & $(0.893)$ & & \\
\hline Local seasonal labor $(0 \mid 1)$ & $2.6 * *$ & $(0.007)$ & 2.0 & $(0.059)$ & $3.2 * * *$ & $(<0.001)$ \\
\hline Credit constrained $(0 \mid 1)$ & 1.7 & $(0.061)$ & 1.7 & $(0.096)$ & 1.7 & $(0.066)$ \\
\hline Fixed capital (log), thsnd. USD & $0.7 * * *$ & $(<0.001)$ & $0.7 * * *$ & $(<0.001)$ & & \\
\hline Machinery (log), thsnd. USD & $1.3 *$ & $(0.030)$ & 1.2 & $(0.112)$ & & \\
\hline Manager female $(0 \mid 1)$ & 1.6 & $(0.076)$ & 1.5 & $(0.125)$ & 1.5 & $(0.107)$ \\
\hline Manager's education level (1...8) & 1.0 & $(0.727)$ & 1.0 & $(0.891)$ & 1.0 & $(0.928)$ \\
\hline Manager's college education $(0 \mid 1)$ & 1.5 & $(0.339)$ & 1.3 & $(0.536)$ & 1.5 & $(0.331)$ \\
\hline Manager's ag. training $(0 \mid 1)$ & 1.0 & $(0.874)$ & 1.0 & $(0.864)$ & 1.0 & $(0.843)$ \\
\hline Manager's age, years & 1.0 & $(0.217)$ & 1.0 & $(0.386)$ & 1.0 & $(0.096)$ \\
\hline Manager's trust in farmers $(1 \ldots 5)$ & 1.2 & $(0.133)$ & 1.1 & $(0.213)$ & 1.1 & $(0.176)$ \\
\hline Manager's trust in investors $(1 \ldots 5)$ & 1.1 & $(0.375)$ & 1.1 & $(0.579)$ & 1.1 & $(0.367)$ \\
\hline Manager's trust in the state $(1 \ldots 5)$ & 0.9 & $(0.195)$ & 0.9 & $(0.281)$ & 0.9 & $(0.336)$ \\
\hline Land losing likelihood $(1 \ldots 5)$ & $1.8 * * *$ & $(<0.001)$ & $1.7 * * *$ & $(<0.001)$ & $1.8 * * *$ & $(<0.001)$ \\
\hline Farm's age, years & 1.0 & $(0.590)$ & 1.0 & $(0.894)$ & 1.0 & $(0.575)$ \\
\hline Akmola $(0 \mid 1)$ & $24.0 * * *$ & $(<0.001)$ & $27.5 * * *$ & $(<0.001)$ & $21.5 * * *$ & $(<0.001)$ \\
\hline Altai $(0 \mid 1)$ & 1.9 & $(0.251)$ & 1.5 & $(0.438)$ & 1.9 & $(0.146)$ \\
\hline Novosibirsk (0|1) & 0.3 & $(0.050)$ & $0.2 *$ & $(0.014)$ & 1.0 & $(0.947)$ \\
\hline Belgorod $(0 \mid 1)$ & $7.5 * * *$ & $(<0.001)$ & $8.9 * * *$ & $(<0.001)$ & $7.4 * * *$ & $(<0.001)$ \\
\hline Ryazan $(0 \mid 1)$ & $9.9 * * *$ & $(<0.001)$ & $10.4 * * *$ & $(<0.001)$ & $14.2 * * *$ & $(<0.001)$ \\
\hline Pseudo R-squared & 0.363 & & 0.375 & & 0.333 & \\
\hline Coef. of discrimination & 0.433 & & 0.444 & & 0.398 & \\
\hline AUC & $87.3 \%$ & & $87.7 \%$ & & $86.2 \%$ & \\
\hline Likelihood-ratio chi-squared & $368.6^{* * *}$ & If: 35$)$ & $380.9^{* * *}$ & $f: 38)$ & $338.2 * * *$ & f: 29$)$ \\
\hline Log likelihood & -323.6 & & -317.5 & & -338.8 & \\
\hline Degrees of freedom & 736 & & 733 & & 742 & \\
\hline No. of observations & 771 & & 771 & & 771 & \\
\hline
\end{tabular}

$1 * * * P<0.001, * * P<0.01, * P<0.05$.

${ }^{2}$ Odds ratios are reported for each model and parameters along with $P$-values of the significance tests in parentheses. We do not report reverse dummy variables representing zero and unreported capital, machinery, labor and land input. 
The effect of the land area share that is rented-in confirms H1b, as it increases the odds of CSR engagement, making farms with all land rented-in two times more likely to engage in CSR than farms with no land rentedin. Nevertheless, the mean predicted probabilities of CSR given the share of land area rented (and keeping all other continuous variables at means and indicator variables at zero) range between 2.4 and $5 \%$ in Model 1 and 2 and $3.6 \%$ in Model 3.

Regarding $\mathrm{H} 2 \mathrm{a}$ and $\mathrm{H} 2 \mathrm{~b}$, we do not find significant effects of labor on CSR involvement. Neither total labor endowment in FTE combined with the share of seasonal labor (Models 1 and 3) nor the separate inclusion of permanent and seasonal labor in FTE (Model 2) have any statistically significant effect on the CSR odds ratio. However, when the farm sourced seasonal labor from the local community (as declared by the farmer), the odds increased by a factor of 2.6 to 3.2 .

Contrary to expectations in $\mathrm{H} 3$, the effect of a credit constraint is positive, and it increases the odds of CSR by 1.7 for farmers facing quantity and liquidity constraints. However, these effects are only statistically significant at the 0.1 level across all models. Finally, we did not find significant effects of trust-related variables (H4).

In support of $\mathrm{H} 5$, the regression results show that with a $1 \%$ increase in farm size, the odds of performing CSR activities increase by $0.4 \%$ (Model 1 and Model 3 ). In addition, it does not matter exactly how the farm increases size. The odds of CSR increase by 0.32 or $0.4 \%$ for farms increasing land use by $1 \%$ through purchase or rental, respectively.

As another measure of farm size, an increase in the book value of capital (in thousands 2019 USD) by 1\% reduces the odds of CSR by approximately $0.4 \%$ (Models 1 and 2). The effect of the book value of machinery (in thousands 2019 USD) is the opposite, as a 1\% rise in the machinery value increases the odds of CSR by $0.24 \%$ (Model 1). The simultaneous exclusion of both variables in Model 3 does not affect the other parameter estimates. Nevertheless, we need to treat these results cautiously, as $23 \%$ of observations in fixed capital and machinery were reported as zero. Such cases are plausible, as old machinery or fixed capital could still be in use but fully depreciated and contain zero book value. In addition, $5 \%$ of observations were not reported at all. To compensate for missing values and zero-reported values, we introduced four reverse dummy variables following Battese (1997) (Supplementary Table S4); therefore, systematic self-selectivity may affect these two variables.

Only eight farms out of 771 indicated that they belonged to an agroholding, out of which six reported conducting any CSR activities. Thus, the number of agroholdings in the sample is too low to draw conclusions with any statistical power (Hosmer et al., 2013: 401-408). In the context of H6, the limited available evidence indicates that agroholdings regularly engage in CSR.

The effect of cooperation with other farms is positive and statistically significant at the $10 \%$ level. However, only 37 farms indicated engaging in formal cooperation, and 20 of them performed CSR. This is weak evidence in favor of $\mathrm{H} 8$.

All three models speak in favor of $\mathrm{H7}$, showing strong and robust evidence that being an individual farm increases the odds of engaging in CSR by a factor of 2.5. Supplementary Figure S1 provides additional descriptive statistics on this outcome.

We also find strong evidence in favor of $\mathrm{H} 9$, as producing livestock increases the odds of CSR between 1.82.0 in all models. At the same time, the effect of crop production remains rather insignificant.

Individual-level factors such as manager age, gender and education (H10, H11, H12) have no statistically significant effect on CSR engagement across the three model specifications. 


\section{Discussion and conclusions}

The present paper focuses on socially responsible activities of farms in Russia and Kazakhstan. We use farm survey data from both countries and apply the multilevel framework of CSR to understand the drivers of farms' CSR engagement arising at the institutional, organizational and individual levels. In doing so, we go beyond existing research on CSR in post-Soviet agriculture in a number of ways. First, unlike other studies, we address all three levels of CSR simultaneously. Second, unlike most studies on farms' CSR in transition countries, we assess the factors of CSR quantitatively. Third, our model includes several previously unaccounted transition-specific factors. We consider farms' characteristics with regard to land use structure, labor hiring, corporate and individual ownership, specialization and perceptions of the strength of existing institutions.

At the institutional level of analysis, our findings demonstrate that the suggested need to address weaknesses of the general legal system of a transition economy (Gagalyuk et al., 2018) is not perceived as an important motive for farms to engage in CSR. Farmers' trust (or mistrust) in the courts' conflict resolution capacity has no significant effect on farms' CSR engagement. Rather, farms' CSR activities in the form of rural infrastructural support are likely to address the uncertainties of local institutional environments, associated primarily with the risk of losing land and dependence on local labor supply. This finding is generally in line with previous research (Bavorová et al. 2021; Visser et al., 2019). However, given that not only large and powerful agroholdings but also small and medium-sized farms are the focus of our study, this finding also reveals that the role of the farming sector in local power configurations appears to be generally less dominant than previously suggested by these authors. Here, CSR seems to result from local power imbalances favoring large agroholdings, local authorities and landowners. In the future, a more detailed research focus on the local institutional environments can shed more light on existing power configurations and their role in farms' social engagement.

However, the growth motivations of farms themselves seem to drive farms' exposure to greater societal pressures. Our results at the organizational level show that the likelihood of CSR engagement increases with increasing farm size. Farms that both lease and own larger land areas are more likely to engage in CSR. Previous research has underlined land lease as a factor that makes farms conduct CSR to address the uncertain lessee-landowner relationships in transition countries (Gagalyuk et al., 2018; Visser et al., 2019). Our novel finding is that a farm's ownership of land increases the likelihood of the farm's CSR. On the one hand, this result points to a potentially positive effect of farms' embeddedness within local communities through land ownership on farms' social conduct. This proposition is supported by a strong effect of local labor sourcing, but not the amount of labor a farm employs, on the farms' CSR. On the other hand, the effect of land ownership has to be juxtaposed with a strong effect of land use insecurity and power imbalances on the institutional level, which implies that landowners may fear losing land just as land lessees do.

One possible reason for this finding is the presence of individual farms in our sample. In contrast to corporate farms, individual farms operate mainly on their own land..$^{2}$ At the same time, they are considerably smaller and have less power on the land market than corporate and agroholding-affiliated farms, and thus, they may be concerned about the resilience of their own operations. To this end, our results demonstrate that individual farm ownership makes farms' engagement in CSR more likely. We also find that a farm's CSR engagement tends to increase if the farm is affiliated with an agroholding. Higher visibilities towards the general public and legitimacy problems related to distributional injustice have previously been discussed as drivers of the CSR of agroholdings (Gagalyuk et al., 2018; Visser et al., 2019). In this study, the positive effects of both individual farm ownership and agroholding affiliation imply a nonlinear relationship between farm size and CSR engagement (Udayasankar, 2008): small individual farms and large agroholding-affiliated farms are more CSR oriented than medium-sized farming enterprises.

${ }^{2}$ This holds only for Russian individual farms. In Kazakhstan, all farms operate leased land due to the specifics of local land market regulations (Kvartiuk and Petrick, 2021). 
However, our analysis shows a lower likelihood of CSR engagement by farms with a greater value of assets. We relate this result to the need of farms with large asset endowments to commit vast farm resources to maintain and operate those endowments, which reduces the possibility of using resources for other purposes, e.g. CSR. In addition, investments in those assets are mostly credit financed (Epshtein et al., 2013), which makes farms spend additional resources on service debts. Another farm-level characteristic - the share of livestock production on a farm - is positively associated with CSR engagement. Provided that the effect of labor input on CSR is insignificant, we cannot conclude that a higher labor intensity of livestock production (compared with crop production) makes farms care more about employees as part of these CSR activities. Rather, more CSR on the part of livestock-producing farms can be attributed to their role as an 'infrastructure improver' in a region. Associated with high capital intensity, livestock farms attract a large volume of statesubsidized investments to build new production facilities (Epshtein et al., 2013). These construction works involve not only farm buildings but also access roads, electricity lines, wastewater disposal and sanitation facilities. Another reason why livestock farms would engage in CSR is their closer consumer proximity than pure crop farms. Livestock farms, especially in Russia, are often vertically integrated with processing facilities and have their own brands. Along with infrastructural improvements, these enterprises may engage in explicit, Anglophone-type CSR activities (Visser et al., 2019) to gain a positive public image for their brands.

At the individual level, we do not find any significant effect of farm managers' characteristics on CSR engagement. This result is similar to the findings by Bavorová et al. (2021) and suggests using a different set of individual-level indicators in future studies of CSR in the region.

\section{Study limitations and outlook on future research}

Our results suggest more future research into farms' local institutional environments. A focus on farms' organizational fields is one of the promising ways to address this suggestion. The concept of organizational field has been recognized as a useful level of analysis in the domains of institutional theory (Scott, 1991; Wooten and Hoffman, 2008). It builds on the premise that an organization's actions are structured by the network of relationships within which it is embedded (Wooten and Hoffman, 2008). This network represents a population of organizations operating in the same industry, including organizations' stakeholders who may impose a coercive, normative or mimetic influence on organizations (DiMaggio and Powell, 1983). Therefore, the notion of organizational field provides a useful theoretical lens to give a detailed account of local power configurations as a driver of farms' CSR engagement.

Another direction for scrutiny of farms' local institutional environments involves focusing on the characteristics of the provinces in which the farms operate. Our results demonstrate strong differences among provinces with regard to farms' engagement in socially responsible activities. In particular, these differences may be subject to provincial institutional settings in countries with a federal form of government such as Russia. Therefore, we propose a more detailed analysis of local power configurations, historical developments, socioeconomic indicators, farm structures and their role in farm social engagement in the future.

Future research on the drivers of farms' CSR should also strengthen our understanding of the role of a generic institutional environment and its interplay with local institutions. Our study uses a perception-based measure of the weakness of a country's legal system and finds no statistically significant effect of it on farms' CSR engagement. We suggest future research efforts to address this limitation and employ a wider scope of indicators measuring the generic institutional environment. These may include indices of economic freedom, corruption perceptions and political constraints (Garrido et al., 2014). Studies incorporating such measures may be particularly insightful with respect to the role of a level playing field in explaining motivations for and abilities of CSR engagement among different farm types.

Future qualitative and quantitative inquiries into the drivers of CSR in transition economies will benefit from disentangling the effects of regulatory, normative and cultural-cognitive institutions (Scott, 1995) on CSR engagement. Our results emphasize the need of farms to engage in CSR to reduce the uncertainties 
associated with land and labor relations. However, how much of that need is caused by the gaps in existing formal institutions and how much of it stems from norms and values prevailing among farms' stakeholders remains to be studied. The latter is particularly interesting in view of our results that produced no significant evidence of the individual farm managers' backgrounds on CSR. One way to obtain more in-depth insights on the individual level of analysis is to inquire explicitly about the personal motives of farm managers to conduct CSR. Moreover, a clear distinction between moral and instrumental rationales needs to be made. Lastly, it would be important to explore whether and to what extent the individual motives of farm managers are induced by their farms' corporate culture.

\section{Supplementary material}

Supplementary material can be found online at https://doi.org/10.22434/IFAMR2020.0197

Table S1. Breakdown of the sample size by country and year and reasons for dropouts.

Table S2. Summary statistics.

Table S3. Country specific summary statistics.

Table S4. Frequency of zero and missing observations.

Figure S1. CSR engagement by province and farm type.

\section{Acknowledgements}

Data collection benefited from financial support by the Federal Ministry of Food and Agriculture (BMEL, Geruka, FKZ 2811HS023) for wave one conducted in 2015 as well as Volkswagen Stiftung (AGRICHANGE, AZ 89821), Federal Ministry of Education and Research (BMBF, ANICANET, FKZ 01DK17031) and Leibniz Competition (LaScalA, SAW-2017-IAMO-2) for wave two. Martin Petrick's work on this article was supported by the German Academic Exchange Service (DAAD) from funds of the Federal Ministry for Economic Cooperation (BMZ), SDGnexus Network (grant number 57526248), program 'exceed Hochschulexzellenz in der Entwicklungszusammenarbeit'. The publication of this article was funded by the Open Access Fund of the Leibniz Association.

\section{References}

Adams, R.B. and D. Ferreira. 2009. Women in the boardroom and their impact on governance and performance. Journal of Financial Economics 94(2): 291-309.

Adams, M. and P. Hardwick. 2002. An analysis of corporate donations: United Kingdom evidence. Journal of Management Studies 35(5): 641-654.

Aguilera, R.V., D.E. Rupp, C.A. Williams and J. Ganapathi. 2007. Putting the S back in corporate social responsibility: a multilevel theory of social change in organizations. The Academy of Management Review 32(3): 836-863.

Aguinis, H. and A. Glavas. 2012. What we know and don't know about corporate social responsibility: a review and research agenda. Journal of Management 38(4): 932-968.

Amaeshi, K., B.C. Adi, C. Ogbechie and O.O. Amao. 2006. Corporate social responsibility in Nigeria: Western mimicry or indigenous influences? SSRN. https://doi.org/10.2139/ssrn.896500

Arato, M., S. Speelman, and G. Van Huylenbroeck. 2016. Corporate social responsibility applied for rural development: an empirical analysis of firms from the American continent. Sustainability 8(1): 102.

Balmann, A., L. Chatalova, V. Valentinov, and T. Gagalyuk. 2016. When growth obliges: social responsibility of farms in light of the technological treadmill. Paper presented at: $149^{\text {th }}$ EAAE Seminar 'Structural change in agri-food chains: new relations between farm sector, food industry and retail sector'. October 27-28, 2016. Rennes, France. Available at: https://ageconsearch.umn.edu/record/245072/

Barney, J. 1991. Firm resources and sustained competitive advantage. Journal of Management 17(1): 99-120.

Battese, G.E. 1997. A note on the estimation of Cobb-Douglas production functions when some explanatory variables have zero values. Journal of Agricultural Economics 48(1-3): 250-252. 
Bavorová, M., Z. Bednarikova, E.V. Ponkina and O. Visser. 2021. Agribusiness social responsibility in emerging economies: effects of legal structure, economic performance and managers' motivations. Journal of Cleaner Production 289: 125157. https://doi.org/10.1016/j.jclepro.2020.125157

Bear, S., N. Rahman and C. Post. 2010. The impact of board diversity and gender composition on corporate social responsibility and firm reputation. Journal of Business Ethics 97(2): 207-221.

Bednaříková, Z., M. Bavorová and E.V. Ponkina. 2016. Migration motivation of agriculturally educated rural youth: the case of Russian Siberia. Journal of Rural Studies 45: 99-111.

Boulouta, I. 2013. Hidden connections: the link between board gender diversity and corporate social performance. Journal of Business Ethics 113(2): 185-197.

Bourlakis, M., G. Maglaras, E. Aktas, D. Gallear and C. Fotopoulos. 2014. Firm size and sustainable performance in food supply chains: insights from Greek SMEs. International Journal of Production Economics 152(C): 112-130.

Brammer S. and A. Millington. 2006. Firm size, organizational visibility and corporate philanthropy: an empirical analysis. Business Ethics: A European Review 15(1): 6-18.

Campbell, J.L. 2007. Why would corporations behave in socially responsible ways? An institutional theory of corporate social responsibility. The Academy of Management Review 32(3): 946-967.

DiMaggio, P.J. and W.W. Powell. 1983. The iron cage revisited: Institutional isomorphism and collective rationality in organizational fields. American Sociological Review 48(2): 147-160.

Dudwick, N., K. Fock and D. Sedik. 2007. Land reform and farm restructuring in transition countries: the experience of Bulgaria, Moldova, Azerbaijan, and Kazakhstan. World Bank Working Paper No. 104. World Bank, Washington, DC, USA.

Epshtein, D., K. Hahlbrock and J. Wandel. 2013. Why are agroholdings so pervasive in Russia's Belgorod oblast? Evidence from case studies and farm-level data. Post-Communist Economies 25(1): 59-81.

Fifka, M.S. and M. Pobizhan. 2014. An institutional approach to corporate social responsibility in Russia. Journal of Cleaner Production 82: 192-201.

Gagalyuk, T. 2017. Strategic role of corporate transparency: the case of Ukrainian agroholdings. International Food and Agribusiness Management Review 20(2): 257-278.

Gagalyuk, T. and F. Schaft. 2016. Corporate social responsibility in agribusiness. Agriculture policy report. German-Ukrainian Agricultural Policy Dialogue, Kyiv, Ukraine. Available at: https://www.apdukraine.de/images/APD_APR_08-2016_CSR_in_Ukrainian_agriculture_eng.pdf

Gagalyuk, T., V. Valentinov and F. Schaft. 2018. The corporate social responsibility of Ukrainian agroholdings: the stakeholder approach revisited. Systemic Practice and Action Research 31(6): 675-698.

Gagalyuk, T. and V. Valentinov. 2019. Agroholdings, turbulence, and resilience: the case of Ukraine. Journal for East European Management Studies 24(3): 484-496.

Garrido, E., J. Gómez, J.P. Maicas and R. Orcos. 2014. The institution-based view of strategy: how to measure it. BRQ Business Research Quarterly 17(2): 82-101.

Graubner, M., I. Ostapchuk and T. Gagalyuk. 2021. Agroholdings and land rental markets: a spatial competition perspective. European Review of Agricultural Economics 48(1): 158-206.

Greene, W.H. 2020. Econometric analysis, $8^{\text {th }}$ edition. Pearson, Harlow, UK.

Grouiez, P. 2014. Farming strategies regarding 'social responsibility' in the Russian agricultural sector. East-West Journal of Economics and Business 17(1): 63-84.

Hajdu, A., M.F. Daziano and O. Visser. in press. Institutions and individual values motivating corporate social responsibility activities in large farms and agroholdings. International Food and Agribusiness Management Review. https://doi.org/10.22434/IFAMR2020.0103

Hartmann, M. 2011. Corporate social responsibility in the food sector. European Review of Agricultural Economics 38(3): 297-324.

Hermans, F., F.R. Chaddad, T. Gagalyuk, S. Senesi and A. Balmann. 2017. The emergence and proliferation of agroholdings and mega farms in a global context. International Food and Agribusiness Management Review 20(2): 175-186. 
Heyder, M. and L. Theuvsen. 2008. Legitimating business activities using corporate social responsibility: is there a need for CSR in agribusiness? Conference Paper/Presentation No. 695-2016-47627. European Association of Agricultural Economists (EAAE) $110^{\text {th }}$ Seminar. February 18-22, 2008. InnsbruckIgls, Austria, pp. 175-187. https://doi.org/10.22004/ag.econ.49851

Heyder, M. and L. Theuvsen. 2012. Determinants and effects of corporate social responsibility in German agribusiness: a PLS model. Agribusiness 28(4): 400-420.

Ho, L.-C.J. and M.E. Taylor. 2007. An empirical analysis of triple bottom-line reporting and its determinants: evidence from the United States and Japan. Journal of International Financial Management and Accounting 18(2): 123-150.

Hosmer, D.W., S. Lemeshow and R.X. Sturdivant. 2013. Applied logistic regression, $3^{\text {rd }}$ edition. John Wiley \& Sons, Inc., Hoboken, NJ, USA.

Jauernig, J. and V. Valentinov. 2019. CSR as hypocrisy avoidance: a conceptual framework. Sustainability Accounting, Management and Policy Journal 10(1): 2-25.

Kvartiuk, V. and M. Petrick. 2021. Liberal land reform in Kazakhstan? The effect on land rental and credit markets. World Development 138: 105285. https://doi.org/10.1016/j.worlddev.2020.105285

Kvartiuk, V., M. Petrick, M., Bavorová, Z. Bednaříková and E. Ponkina. 2020. A brain drain in Russian agriculture? Migration sentiments among skilled Russian rural youth. Europe-Asia Studies 72(8): 1352-1377.

Larrieta-Rubín de Celis, I., E. Velasco-Balmaseda, S. Fernández de Bobadilla, M.D.M. Alonso-Almeida and G. Intxaurburu-Clemente. 2015. Does having women managers lead to increased gender equality practices in corporate social responsibility? Business Ethics, the Environment and Responsibility 24(1): 91-110.

Lerman, Z., C. Csaki and G. Feder. 2004. Agriculture in transition. Land policies and evolving farm structures in post-Soviet countries. Lexington Books, Lanham, MD, USA.

Lin, K.Z., S. Cheng and F. Zhang. 2017. Corporate social responsibility, institutional environments, and tax avoidance: evidence from a subnational comparison in China. The International Journal of Accounting 52(4): 303-318.

Li, W. and R. Zhang. 2010. Corporate social responsibility, ownership structure, and political interference: evidence from China. Journal of Business Ethics 96(4): 631-645.

Lioubimtseva, E. and G.M. Henebry. 2012. Grain production trends in Russia, Ukraine and Kazakhstan: new opportunities in an increasingly unstable world? Frontiers of Earth Science 6(2): 157-166.

Matten, D. and J. Moon. 2008. 'Implicit' and 'explicit' CSR: a conceptual framework for a comparative understanding of corporate social responsibility. Academy of Management Review 33(2): 404-424.

McElroy, K.M. and J.J. Siegfried. 1985. The effect of firm size on corporate philanthropy. Quarterly Review of Economics and Business 25(2): 18-26.

McWilliams, A. and D.S. Siegel. 2000. Corporate social responsibility and financial performance: correlation or misspecification? Strategic Management Journal 21(5): 603-609.

Nizalov, D., S. Thornsbury, S. Loveridge, M. Woods and O. Zadorozhna. 2015. Dynamics of agricultural production and land use in post-soviet Ukraine. In: A. Schmitz and W. Meyers (eds.) Transition to agricultural market economies: the future of Kazakhstan, Russia and Ukraine. Cabi International, Wallingford, UK, pp. 215-227.

Orlitzky, M. 2001. Does firm size confound the relationship between corporate social performance and firm financial performance? Journal of Business Ethics 33(2): 167-180.

Oshakbayev, D., R. Taitukova, M. Petrick and N. Djanibekov. 2018. Kazakhstan's cotton sector reforms since independence. Discussion Paper No. 172. Leibniz Institute of Agricultural Development in Transition Economies (IAMO), Halle (Saale), Germany. Available at: https://www.econstor.eu/ bitstream/10419/173255/1/1011202573.pdf

Pallot, J. and T. Nefedova. 2007. Russia's unknown agriculture. Household production in post-socialist rural Russia, $1^{\text {st }}$ edition. Oxford University Press, Oxford, UK.

Panwar, R., K. Paul, E. Nybakk, E. Hansen and D. Thompson. 2014. The legitimacy of CSR actions of publicly traded companies versus family-owned companies. Journal of Business Ethics 125(3): 481-496. 
Petrick, M. and L. Götz. 2019. Herd growth, farm organisation and subsidies in the dairy sector of Russia and Kazakhstan. Journal of Agricultural Economics 70(3): 789-811.

Petrick, M. and D. Oshakbaev. 2015. Kazakhstan's agricultural development constraints: evidence from the wheat, beef and dairy sectors. In: A. Schmitz and W.H. Meyers (eds.) Transition to agricultural market economies: the future of Kazakhstan, Russia, and Ukraine. CABI, Wallingford, UK, pp. 15-26.

Petrick, M., D. Oshakbaev and J. Wandel. 2017. More than pouring money into an ailing sector? Farm-level financial constraints and Kazakhstan's 'Agribusiness 2020' strategy. In: S. Gomez y Paloma, S. Mary, S. Langrell and P. Ciaian (eds.) The Eurasian wheat belt and food security. Global and regional aspects. Springer, New York, NY, USA, pp. 103-118.

Petrick, M., J. Wandel and K. Karsten. 2013. Rediscovering the virgin lands: agricultural investment and rural livelihoods in a Eurasian frontier area. World Development 43: 164-179.

Pisani, N., A. Kourula, A. Kolk and R. Meijer. 2017. How global is international CSR research? Insights and recommendations from a systematic review. Journal of World Business 52(5): 591-614.

Quazi, A.M. 2003. Identifying the determinants of corporate managers' perceived social obligations. Management Decision 41(9): 822-831.

Scott, W.R. 1991. Unpacking institutional arguments. In: W.W. Powell and P.J. DiMaggio (eds.) The new institutionalism in organizational analysis. University of Chicago Press, Chicago, IL, USA, pp. 164-182.

Scott, W.R. 1995. Institutions and organizations. SAGE Publications, Thousand Oaks, CA, USA.

Setó-Pamies, D., 2015. The relationship between women directors and corporate social responsibility. Corporate Social Responsibility and Environmental Management 22(6): 334-345.

Smedley, T. 2012. Is it time for the cooperative as a more viable alternative for business? The Guardian, 9 July 2012. Available at: https://www.theguardian.com/sustainable-business/co-operative-viablealternative-business-model

Soares, R., C. Marquis and M. Lee. 2011. Report: gender and corporate social responsibility: It's a matter of sustainability. Catalyst, 11 November 2011. Available at: https://www.catalyst.org/research/genderand-corporate-social-responsibility-its-a-matter-of-sustainability/

Stanwick, P.A. and S.D. Stanwick. 1998. The relationship between corporate social performance, and organizational size, financial performance, and environmental performance: an empirical examination. Journal of Business Ethics 17(2): 195-204.

Tilt, C.A., 2016. Corporate social responsibility research: the importance of context. International Journal of Corporate Social Responsibility 1(2): 1-9. https://doi.org/10.1186/s40991-016-0003-7

Tjur, T. 2009. Coefficients of determination in logistic regression models - a new proposal: the coefficient of discrimination. The American Statistician 63(4): 366-372.

Tleubayev, A., I. Bobojonov, T. Gagalyuk and T. Glauben. 2020. Board genderd diversity and firm performance: evidence from Russian agri-fodd industry. International Food and Agribusiness Management Review 23(1): 35-54.

Udayasankar, K. 2008. Corporate social responsibility and firm size. Journal of Business Ethics 83(2): 167-175.

Unay-Gailhard, İ., M. Bavorová, Z. Bednaříková, Z. and E.V. Ponkina. 2019. 'I don’t want to work in agriculture!' The transition from agricultural education to the labor market in rural Russia. Rural Sociology 84(2): 315-349.

Vaz, N., B. Fernandez-Feijoo and S. Ruiz. 2016. Integrated reporting: an international overview. Business Ethics, the Environment and Responsibility 25(4): 577-591.

Visser, O., A. Kurakin and A. Nikulin. 2019. Corporate social responsibility, coexistence and contestation: large farms' changing responsibilities vis-à-vis rural households in Russia. Canadian Journal of Development Studies/Revue canadienne d'études du développement 40(4): 580-599.

Visser, O., N. Mamonova and M. Spoor. 2012. Oligarchs, megafarms and land reserves: understanding land grabbing in Russia. The Journal of Peasant Studies 39(3-4): 899-931.

Wädekin, K.-E. 1973. The private sector in Soviet agriculture, $2^{\text {nd }}$ edition. University of California Press, Berkley, CA, USA.

Wegren, S.K. 2009. Land reform in Russia. Institutional design and behavioral responses. Yale University Press, New Haven, CT, USA. 
Wegren, S.K., 2018. The 'left behind': smallholders in contemporary Russian agriculture. Journal of Agrarian Change 18(4): 913-925.

Wegren, S.K. and C. Elvestad. 2018. Russia's food self-sufficiency and food security: an assessment. PostCommunist Economies 30(5): 565-587.

Wernerfelt, B., 1984. A resource-based view of the firm. Strategic Management Journal 5(2): 171-180.

White, A. 2007. Internal migration trends in Soviet and post-Soviet European Russia. Europe-Asia Studies 59(6): 887-911.

Williamson, O.E., 1983. Credible commitments: using hostages to support exchange. The American Economic Review 73(4): 519-540.

Williamson, O.E., 1996. The mechanisms of governance. Oxford University Press, Oxford, UK.

Wood, D.J. 1991. Corporate social performance revisited. The Academy of Management Review 16(4): 691-718.

Wooten, M. and A.J. Hoffman. 2008. Organizational fields: past, present and future. In: R. Greenwood, C. Oliver, R. Suddaby and K. Sahlin (eds.) The Sage handbook of organizational institutionalism. SAGE Publications, Thousand Oaks, CA, USA, pp.131-147.

Zhang, J.Q., H. Zhu and H.-B. Ding. 2013. Board composition and corporate social responsibility: an empirical investigation in the post Sarbanes-Oxley era. Journal of Business Ethics 114(3): 1-12. 